\title{
Energy security problems and features of its research at the present stage
}

\author{
Natalia Pyatkova ${ }^{1, *}$, Victor Rabchuk ${ }^{1}$ \\ ${ }^{1}$ Melentiev Energy Systems Institute, 130 Lermontov str., Irkutsk, Russia
}

\begin{abstract}
The paper offers a modern interpretation of the term "energy security". Strategic threats to energy security are identified for the modern conditions; their dynamics and transformation are shown at different time stages of the Russian energy sector development. Also the work presents methodological and modeling developments on the study of energy security problems. A scheme is proposed for researching the country's fuel and energy complex, taking into account the requirements of energy security, the methods and models used are analyzed. The paper describes the features and new challenges in the research of energy security at present and the need to develop modern methods, models and tools.
\end{abstract}

\section{Introduction}

In recent years, there has been a sharp increase in interest in the issue of energy security (ES). To date, the problems of ES have been outlined and numerous publications on this problem have been published.

For the first time, issues of energy security were recognized as a problem in industrialized countries during the oil crisis of 1973-74, when, following the next outbreak of the Middle East conflict, a multiple increase in oil prices followed. At the same time, the essence of ES was formulated by the World Energy Council: ES is the belief that energy will be available in the quantity and quality that are required under given economic conditions. To date, a collection of articles by foreign researchers on various aspects of energy security was published [1].

The problems of ES in Russia began to be actively discussed after the collapse of the USSR, in the mid1990s - both in connection with acute crisis phenomena in the energy sector of the Russian economy, which threatened serious violations of normal, sustainable energy (electricity, heat, fuel); and in connection with the general increase of attention to different aspects of national security in the conditions of breaking-up of a new social and economic system. By this time, the Federal Law "On Security" (from 05.03.92) was adopted, in which security (actually - national security) is defined as "the state of protection of the vital interests of the individual, society and the state from internal and external threats". In the Institute of Energy Systems of L.A. Melentiev of the Siberian Branch of the Russian Academy of Sciences (ISEM) proposed the definition and interpretation of the concept of "energy security" in the following formulation [2-4]: ES - the state of protection of citizens, society, the state and the economy as a material basis for their existence and progressive development, from threats of shortage in providing their energy needs with economically accessible energy resources of acceptable quality, threats of disruption the continuity of energy supply. The state of security is thus understood as a condition that, under normal conditions, provides for fully justified energy demand, and in extreme conditions, guaranteed assurance of the minimum required volume of needs. Thus, ES is lack of deficit (physical accessibility), continuity (reliability) and economic accessibility of quality energy supply. ES is characterized by three main factors:

- by the ability of the fuel and energy complex (FEC) to provide a sufficient supply of economically available quality energy resources;

- by the ability of the economy (as a system of consumers of energy resources) to rationally (carefully) spend them and, accordingly, to limit their demand, realizing an economically feasible potential for energy saving;

- by a sufficiently high level of sustainability of energy systems, the fuel and energy sector in general, the economy as a whole to disturbing impacts of potential threats to ES.

\section{Scheme of energy security research}

The main content of research in the field of ES and justification of measures to ensure is to predict the conditions of operation and development of energy and fuel and energy complex in general, taking into account the realizing of ES threats; in assessing the state under these conditions and identifying bottlenecks in fuel and energy supply systems consumers, in the choice of possible directions and specific measures to reduce the negative impact of threats in these systems.

\footnotetext{
Corresponding author: nata@isem.irk.ru
} 
This requires appropriate methodological, model and software development. There are many foreign developments in the field of energy modeling.

The main representatives of imitation models of foreign researchers in the field of energy are MARKAL (MARKet ALlocation) [5, 6], EFOM (Energy Flow Optimization Model), MESSAGE (Model for Energy Supply Strategy Alternatives and their General Environmental Impacts).

MARKAL is a numerical model used to carry out economic analysis of different energy related systems at the country level to represent its evolution over a period of usually of 40-50 years. The word MARKAL was generated by concatenating two words (MARKet and ALlocation). Various parameters such as energy costs, plant costs, plant performances, building performance and so on, can be input and the software will choose an optimal technology mix to meet that demand at minimum cost. It is available from the International Energy Agency. TIMES is an evolution of MARKAL and both energy models share many similarities.

TIMES (The Integrated MARKAL-EFOM System) is a bottom-up optimization model generator that allows accurate energy and environmental policy analysis at the local, national or multi-regional level. This tools combines a technical engineering approach and an economic approach to represent technologies, fuels, emissions and their effect on all economic sectors.

The MESSAGE program [7, 8] was developed by the International Institute for Applied Systems Analysis (IIASA) for planning and forecasting the development of energy systems. In fact, this is a modeling system for medium- and long-term planning of energy systems development, energy policy analysis and development scenarios development. This is a flexible tool that allows you to compare alternative energy technologies and build the most appropriate scenario for the development of the energy system. The criterion of expediency is the minimum of the given system costs. To find the optimal solution, the linear programming method is used.
Optimization is carried out on the whole considered prediction interval.

MESSAGE allows you to compare alternative scenarios for the development of the energy system in terms of impact on the environment.

The information-model complex NEMS (National Energy Modeling System) is developed by the US Department of Energy.

NEMS [9] - a system that models the US economy with the allocation of energy to its individual sector. This complex builds forecasts for the production, import, processing, consumption and prices of fuel and energy resources, taking into account macroeconomic and financial indicators, the world market of fuel and energy resources, the choice of certain technologies, the quantitative and qualitative characteristics of the chosen technology, etc. The complex is used to determine the strategy of energy development, the impact of energy on the economy, the environment of the country.

Energy security problems in Russia have a number of features that require the development of original methods, models and software.

To study the energy security problems of Russia, a two-level technology is proposed that integrates the stages of qualitative analysis (using semantic modeling tools) and quantitative analysis (using linear economicmathematical models and traditional software systems). The general scheme of the tasks to be solved and the modeling methods used in assessing the effect of ES threats on the state of energy security are shown in Fig.1.

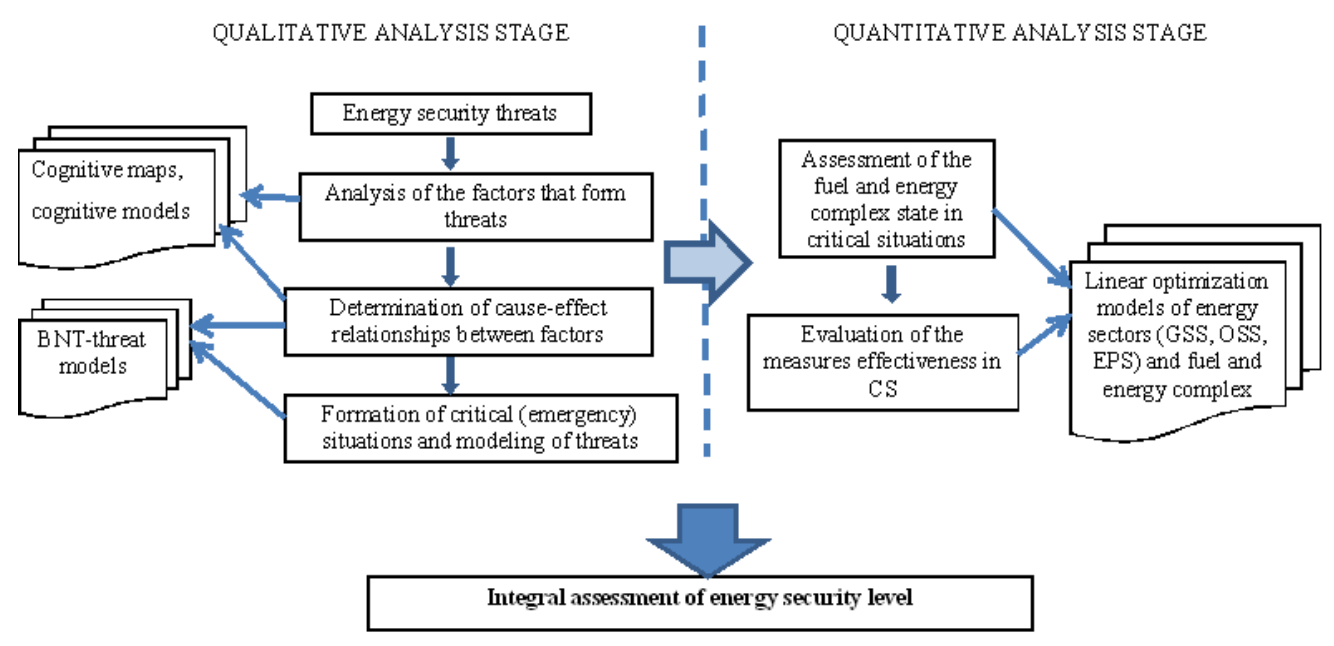

Fig.1. General scheme of studies of ES problems. 
Based on the methodological approaches created in the ISEM of the SB RAS, a scheme has been developed for obtaining an integrated assessment of the level of energy security in the region, based on an indicative analysis of the region's energy security and model studies (Fig. 2) [10].

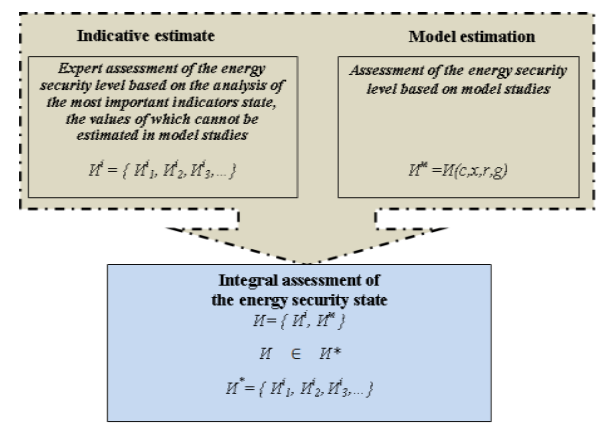

Fig. 2. Scheme of obtaining an integral evaluation of the regional level

To date the most developed methodically the stage of quantitative analysis, which solves the problems of researching the functioning and development of energy, taking into account the requirements of the ES. The basis for research is the technical and economic characteristics of energy facilities and reporting data on the state of energy systems, the results of research on the development of the fuel and energy sector, that justifying the choice of long-term strategy and the formation of energy policy. Based on the socioeconomic program for the development of the country's economy, which determines the demand for fuel and energy resources, an analysis and assessment of energy consumption levels taking into account energy conservation is carried out.

Within the qualitative analysis phase, based on the above characteristics and the analysis of the ES threats, the calculation conditions for the computational experiment are formed, which is carried out at the stage of quantitative analysis.

A two-level system of models was proposed for carrying out experimental studies of energy security problems [4].

To harmonize the models of different levels of the hierarchy in the studies under consideration, a methodical approach is applied that allows solving the corresponding problems in the studies of the fuel and energy complex using a multilevel hierarchy of optimization studies. The interrelation of models and the main solved tasks are shown in Fig. 3.

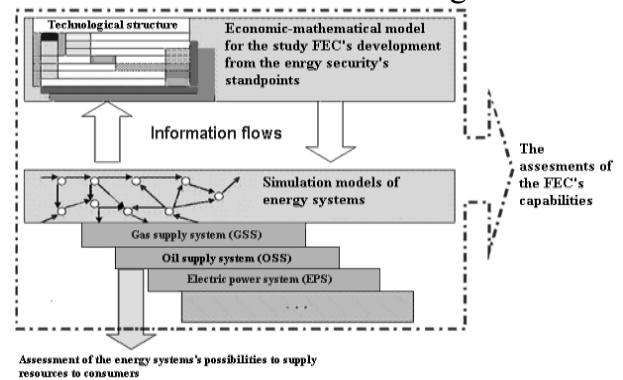

Fig. 3. Interrelation of models of two-level technology and the main tasks to be solved
In this approach, upper-level models are constructed by aggregating low-level models in accordance with conditionally optimal solutions previously obtained for them. The lower-level models are simulation models of energy systems for analyzing the options for their development, assessing the state and identifying "bottlenecks" when operating under different conditions. Aggregate solutions found using top-level models are passed to lower-level models and used by them as boundaries within which a detailed solution is determined.

Using a two-level system of models and methods of combinatorial modeling, studies were conducted on the selection of possible trajectories of the development of the fuel and energy complex with subsequent analysis of these trajectories from the point of ES [11].

\section{Energy security threats and their modeling}

When analyzing the current state of the country's energy sector, the main strategic threats to ES were identified at the present stage, that is, threats that can form today and in the near future a sustained long-term deficit in the country's energy balance:

- insufficient level of investments in the fuel and energy sector;

- energy wastefulness of the economy;

- iinsufficient increments of explored hydrocarbon reserves;

- the dominant role of natural gas in the fuel and energy balance of European regions of Russia;

- reduced opportunities to increase gas production due to the economic risk of developing the gas resources of the Yamal and the shelf of the northern seas;

- high deterioration and low rates of equipment renewal in the fuel and energy sector.

A special place among ES threats is the threat of reducing opportunities to increase gas production, as today the gas in the fuel balance of the country occupies $70-72 \%$, and in some (European) regions of the country reaches $90 \%$ and higher.

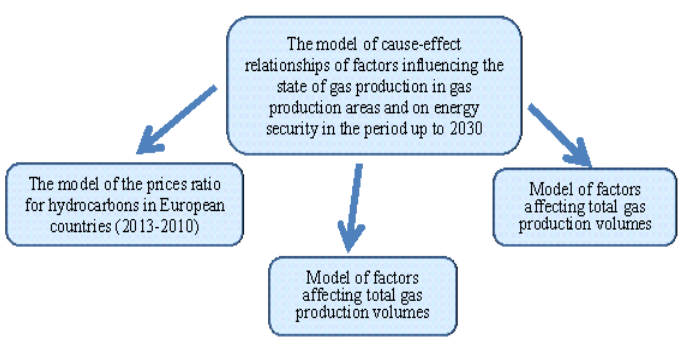

Fig. 4. Models of worsening / improvement for the situation for the strategic threat of ES "Decrease in opportunities to increase gas production"

Using the methods of cognitive modeling for this threat, a system of models of deterioration / improvement of the situation is constructed (Fig. 4), allowing to visualize and link all the factors that form a threat at various time stages [12]. 
To analyze energy security threats and their consequences, it is suggested to create special models using an approach that allows, based on the use of Bayesian networks of trust, to describe the cause-effect relationship between the factors that form threats and lead to the emergencies. This approach makes it possible to take into account the probability of occurrence of the factors underlying the threat being analyzed, or the probability that they will assume a certain state.

The models constructed with the help of Bayesian networks allow taking into account a lot of factors and dependencies between them. A methodology for modeling energy security threats has been developed. With its use, models have been developed $[13,14]$ to assess the consequences of such threats to ES, such as: - low rates of renewal of power generating equipment; - lack of investment (for example, the oil industry); - cool weather with a corresponding increase in the consumption of boiler-furnace fuel and heat and power generation

As an illustrative example, the results of the simulation of the threat "Low rates of renewal of power generating equipment" are shown (Fig. 5).

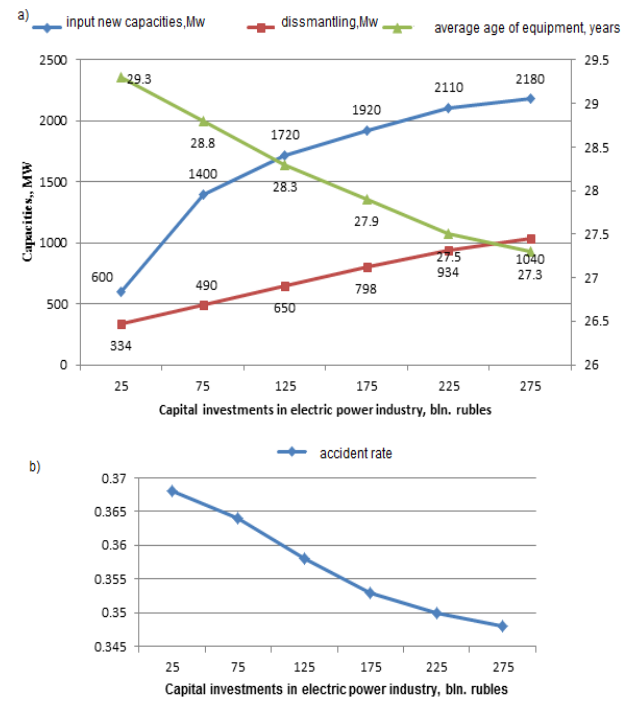

Fig.5. a) volumes of dismantling of old and commissioning of new equipment (MW) and mean age of equipment (years); b) changes in the accident rate in response to increase the volume of capital investments

The increase in investment volumes leads to increased levels of dismantling and equipment commissioning, while upgrading at a faster pace (compared to dismantling) can lead to a slight increase in accident rate due to the introduction of completely new equipment, but it reduces the accident rate sufficiently, compared with initial values.

The performed experimental calculations showed the possibility and expediency of using Bayesian networks of confidence for modeling the process of development of energy security threats with the possibility of assessing the likelihood of realizing the threats themselves (ie, the occurrence of emergencies), the likelihood of the consequences of their implementation and the possibility of assessing the effect of the corresponding compensation and liquidation measures.

\section{Dynamics and transformation of energy security threats}

It is also important to account the possible dynamics and transformation of threats to energy security at different time intervals. The conducted studies show possible changes both in the composition of threats and in the importance (priority) of individual threats at different time stages. Based on the real state of affairs with the provision of Russia's EBC in the period from 2011 to 2016, and the expected state of the same condition for 2020 , the analyzed period is divided into two intervals: from 2021 to 2025 and from 2026 to 2030. Table 1 shows the change in the composition of threats in the future up to 2030 for different time intervals, as well as their possible influence on the energy sector and the economy of the country.

Table 1. Assessment of the direction of transformation of strategic threats to Russia's energy security for the period from 2021 to 2030 .

\begin{tabular}{|c|c|c|c|}
\hline \multirow[t]{2}{*}{$\begin{array}{c}\mathrm{N} \\
/ \\
\mathrm{N}\end{array}$} & \multirow[t]{2}{*}{$\begin{array}{l}\text { The essence of the } \\
\text { strategic threat of } \\
\text { Russia's ES }\end{array}$} & \multicolumn{2}{|c|}{$\begin{array}{c}\text { The direction of the } \\
\text { transformation of the threat } \\
\text { by time intervals }\end{array}$} \\
\hline & & $2021-2025$ & $2026-2030$ \\
\hline 1 & $\begin{array}{l}\text { Lack of investments in } \\
\text { energy sectors }\end{array}$ & $\begin{array}{l}\text { Significant } \\
\text { increase in } \\
\text { threat }\end{array}$ & $\begin{array}{c}\text { Threatening } \\
\text { the threat }\end{array}$ \\
\hline 2 & $\begin{array}{l}\text { Low rates of renewal } \\
\text { of OPF in the energy } \\
\text { sector }\end{array}$ & $\begin{array}{c}\text { Some } \\
\begin{array}{c}\text { increase in the } \\
\text { threat }\end{array}\end{array}$ & $\begin{array}{c}\text { Some } \\
\text { weakening } \\
\text { of the threat }\end{array}$ \\
\hline 3 & $\begin{array}{l}\text { Energy-saving } \\
\text { economy of Russia }\end{array}$ & $\begin{array}{c}\text { Some } \\
\text { weakening of } \\
\text { the threat }\end{array}$ & $\begin{array}{l}\text { Weakening } \\
\text { the threat }\end{array}$ \\
\hline 4 & $\begin{array}{l}\text { Domination of gas in } \\
\text { the FER balances of } \\
\text { the European regions } \\
\text { of the country and the } \\
\text { Urals }\end{array}$ & $\begin{array}{c}\text { Some } \\
\text { weakening of } \\
\text { the threat }\end{array}$ & $\begin{array}{c}\text { Some } \\
\text { weakening } \\
\text { of the threat }\end{array}$ \\
\hline 5 & $\begin{array}{l}\text { Delay with the } \\
\text { development of new } \\
\text { areas of gas production }\end{array}$ & $\begin{array}{l}\text { Strengthening } \\
\text { the threat }\end{array}$ & $\begin{array}{l}\text { Enhancing } \\
\text { the threat }\end{array}$ \\
\hline 6 & $\begin{array}{l}\text { Reduction of gas } \\
\text { production capacity in } \\
\text { the country }\end{array}$ & $\begin{array}{c}\text { Increased } \\
\text { threat }\end{array}$ & $\begin{array}{l}\text { Increased } \\
\text { threat }\end{array}$ \\
\hline 7 & $\begin{array}{l}\text { Reduction of oil } \\
\text { production capacity in } \\
\text { the country }\end{array}$ & - & $\begin{array}{l}\text { Significant } \\
\text { increase in } \\
\text { the threat }\end{array}$ \\
\hline 8 & $\begin{array}{l}\text { A large share of } \\
\text { electricity and heat } \\
\text { produced at large } \\
\text { thermal power plants } \\
\text { and large boiler houses }\end{array}$ & - & $\begin{array}{c}\text { Increased } \\
\text { threat }\end{array}$ \\
\hline
\end{tabular}

The carried out researches on transformation of threats have allowed to determine the separate indicators of energy development. So, in the implementation of strategic threats to the ES without carrying out cardinal measures to overcome them by 
2025-2030. The country may face significant problems for its economic development. The analysis of prospective opportunities of the energy industries production in comparison with domestic needs for fuel and energy resources in this period shows that the tension will increase to meet external obligations for the export of oil and gas. Unless drastic measures are taken, the volume of oil production in Russia by the year 2030 will be 450 million tons (in 2016, the volume of production was 547 million tons), and gas at 620 billion cubic meters (in 2016 - 653 billion cubic meters). It is especially alarming that the opportunities for exporting Russian gas (without taking into account the conjuncture of foreign markets and provided that the country's domestic requirements for gas are fully provided) are drastically reduced and, without taking drastic measures, by 2030 , can be only $80 \mathrm{bcm}$ versus $180 \mathrm{bcm}$ in 2016.

\section{Conclusion}

To date, the ISEM SB RAS has carried out a complex of studies to develop an appropriate scientific and methodological base for studying the problem of energy security. In particular:

- methodical bases of an estimation of a level of ES of the country and its regions, tested at an estimation of level of ES of some regions (subjects of the Russian Federation and federal districts) are developed;

- the role of the gas industry (as dominant in the balance of primary fuel and energy resources) in providing the country's ES is assessed and requirements for the future development of this sector are determined from these positions;

- a system of decision support for the provision of ES, relevant information technology and software are developed;

- the process of conducting model studies of the interconnected work of the fuel and energy complex and the energy systems in the context of the implementation of strategic threats to the ES was prepared and implemented;

- methodical provisions were developed for the formation of directions for adjusting options for the development of the fuel and energy complex of Russia from the ES's point of view.

In addition, with the participation of the Institute, the draft of the Doctrine of Energy Security of Russia (protocol approved by the President of Russia on November 29, 2012, No. 3167) and the Methodology for Monitoring Energy Security in Russia and Regions were developed [15-17].

This work was carried out with the partial support of the Program of the Presidium of the Russian Academy of Sciences I.33P.

\section{References}

1. The Routledge Handbook of energy security / ed. by B.K. Sovacool. (London and New-York, Taylor and Francis Group, 2011, 436 p).

2. V.V. Bushuev, N.I. Voropay and others, Energy security of Russia (SO RAN Publ., Novosibirsk, 1998)

3 Energy security. Terms and definitions (Moscow: Energia, 2005)

4. N.I. Pyatkova, V.I. Rabchuk, S.M. Senderov and others, System research in power engineering: Retrospective of scientific directions of SEI - ISEM. Research in the field of energy security of the country and regions (SO RAN Publ., Novosibirsk, 2010)

5. A. J. Seebregts, G.A. Goldstein, K. Smekens, Energy/Environmental Modeling with the MARKAL Family of Models 2001 Adobe Acrobat Reader. URL: ftp://ftp.ecn.nl/pub/www/library/report/2001/rx01039.p df

6. MARKAL 2011. URL: http://www.iea-etsap.org/ web/Markal.asp

7. MESSAGE. URL:http://www.iiasa.ac.at/web/home/ research/researchPrograms/Energy/MESSAGE.en.html 8. E.V. Fedorova Nuclear energy 4. (2004).

9. The National Energy Modeling System: An review 2009 http://www.eia.doe.gov/oiaf/aeo/overview /index.html

10. N.I. Pyatkova, S.M. Senderov, E.V. Pyatkova Izvestia RAN. Energetika [Proc. of the Russ. Acad. of Sciences. Pow. Engin.], 2, 7. (2014).

11. S.M. Senderov, V.I. Rabchuk, N.I. Pyatkova Izvestia RAN. Energetika [Proc. of the Russ. Acad. of Sciences. Pow. Engin.], 5, 7. (2009).

12. N.I Pyatkova, L.V. Massel, A.G. Massel, Izvestia RAN. Energetika [Proc. of the Russ. Acad. of Sciences. Pow. Engin.], 4, 8. (2016).

13. E.V. Pyatkova, L.V. Massel, Methodological issues of reliability research for large energy systems, 61, 8 . (2011).

14. E.V. Pyatkova Methodological issues of research of large energy systems, 63, 12. (2013).

15. V.V. Bushuev, Voropai N.I., Senderov S.M., Economika regiona, 2, 11 (2012).

16. S.M. Senderov, Methodological recommendations for assessing the state of energy security of the Russian Federation at the federal level (Irkutsk: ISEM SB RAS, 2013).

17. S.M. Senderov, Methodology for monitoring the state of Russia's energy security at the regional level (Irkutsk: ISEM SB RAS, 2014). 